\title{
Aproximación etnográfica del hábitat y habitus auto-representados en las realizaciones audiovisuales de los productores informales en la ciudad de Santo Domingo de los Colorados (Ecuador).
}

\author{
EDUARDO FABIO HENRÍQUEZ MENDONZA \\ Universitad Autonoma de Barcelona, Barcelona, Catalunia, Espanha
}

DOI 10.11606/issn.2316-9133.v27i1p171-199

\begin{abstract}
resumo La presente es una aproximación etnográfica que hace uso de las herramientas de la antropología audiovisual para acceder a las percepciones del hábitat y habitus auto-representados en las realizaciones audiovisuales (películas en formato DVD) de los productores informales en la ciudad de Santo Domingo de los Colorados (Ecuador). A través de las herramientas de la etnografía audiovisual se analizan aspectos de la cultura material, condición económica y parte de sus trayectorias biográficas y profesionales. Este acercamiento ayuda a deducir cómo se representa su percepción de la realidad y cómo estos aspectos influyen directamente en la preproducción, producción y postproducción de sus trabajos. Con estos interrogantes se abordaron también los procesos de realización en cuanto a temáticas, estilos, escenarios y distribución comercial. Teniendo en cuenta el concepto "bricoleur" en cuanto a su actuación espontánea, las escenas improvisadas, y el aprovechamiento de espacios y tiempos.
\end{abstract}

palabras Claves Productores informales; cultura material; narrativas audiovisuales; autorepresentación; ficción.

Ethnographic approximations to habitat and habitus self-represented in audio-visual realizations of informal producers in Santo Domingo de los Colorados (Ecuador)

abstract This paper is an ethnographic approach that uses audio-visual anthropology as a tool to access the perceptions of the self-represented habitat and habitus in audio-visual productions (movies in DVD format) of informal producers in the city of Santo Domingo de los Colorados (Ecuador). Through the tools of ethnographic anthropology, aspects of the material culture, economic condition and part of their biographical and professional trajectory will be analysed. This approach helps in deducing how they represent their perception of reality and how these aspects directly influence the preproduction, production and post production of their work. Along with these questions, the production process in terms of themes, styles, scenarios and commercial distribution, are addressed. Likewise, the experience "bricoleur" of the producers is 
considered in terms of their spontaneous acting (amateur actors and actresses), improvised scenes, and use of time and space, among other factors that give life to the narrative drama like the contexts where these films are shot that contribute originality, strength and intrinsic value to history.

Keywords: informal producers; material culture; audiovisual narratives; self-representation; fiction.

Uma aproximação para uma etnografia do habitat e habitus autorrepresentados nas realizações audiovisuais dos produtores informais na cidade equatoriana de Santo Domingo de los Colorados (Equador)

resumo $\mathrm{O}$ presente artigo é uma abordagem etnográfica que utiliza as ferramentas da antropologia audiovisual para compreender as percepções do habitat e habitus auto-representados nas obras audiovisuais dos produtores informais. Estes produtores têm materializado suas obras em filmes de distribuição local na cidade de Santo Domingo de los Colorados no Equador. Ademais, as ferramentas da etnografia audiovisual descrevem como a cultura, status económico e as trajectórias pessoais e profissionais estão relacionadas com a produção audiovisual. Esta aproximação etnográfica ajuda na descoberta de como as percepções da realidade dos produtores influenciam directamente a pré-produção, produção e pós-produção de seu trabalho. Alem disso, estas questões influem nos processos de realização dos temas, estilos, cenários e distribuição comercial. Também, tendo em conta as experiências "bricoleur" dos produtores em actuação espontânea (atores e atrizes amadores), cenas improvisadas, e o uso do espaço e desempenho do tempo, entre outros factores que dão vida ao drama narrativa como os contextos onde os filmes são filmados estão contribuindo para a originalidade da história, força e valor intrínseco.

palavras-chave produtores informais; Cultura material; Narrativas audiovisuais; Autorepresentação; Ficção.

\section{Narrar la realidad}

Toda realidad narrada se transforma cuando se la interpreta con cualquier medio de comunicación. Pero, el hecho real no pierde toda su verosimilitud, ni mucho menos vigencia cuando se lo representa en el campo de las narrativas orales, escritas, visuales y audiovisuales. Los registros de los sucesos captados por medios digitales y escritos desvanecen las fronteras entre realidad y ficción (GUARINI; De ANGELIS, 2014). La ficción como herramienta de narración audiovisual, se convierte en aliada estratégica al momento de manipular tiempos y espacios. Permitiendo "profundizar una exposición y

\footnotetext{
${ }^{1}$ El presente artículo fundamenta uno de los resultados obtenidos durante la etnografía audiovisual de mi proyecto de investigación doctoral: Análisis de las representaciones en las narrativas audiovisuales de productores informales en Ecuador a partir de una etnografia audiovisual de sus estilos, escenografias y distribuciones comerciales, bajo la dirección: Tutor Jorge Grau Rebollo de la Universidad Autónoma de Barcelona y Co-tutor Juan Ignacio Robles Picón de la Universidad Autónoma de Madrid.
} 
reflexión sobre conflictos, actividades ilegales o asuntos tabúes sin involucrar directamente a las personas" (BOUDREAULT-FOURNIER, NOVAES; HIJIKI, 2017, p. 44). Por ello, las narrativas audiovisuales de los productores informales, término que desarrollo más adelante, permiten registrar en estado vigente voz, sonidos, imágenes, movimientos que en cierta medida convierte el "ficcionar" "en ese acto universal, social y -cultural” (RODRÍGUEZ HERRERO, 2012, p. 5).

Los deseos de un productor audiovisual informal, deseos que no se diferencian de un productor audiovisual formal, están centrados en que sus obras generen diversas emociones al público receptor. La mayoría de las narrativas audiovisuales de los productores informales parten de historias comunes que tratan de representar verosímil y ficcionalmente temas de amor, engaño, violencia, esperanza, superación, tragedia, entre otros hechos cercanos a nuestra realidad. Durante la etnografía se pudo observar que cuanto más un productor informal representa en su narrativa audiovisual la cotidianidad, lo natural, lo común, mayor conexión emocional logrará con su público.

Esta conexión íntima está dominada por la percepción social que el productor informal tiene de la realidad. En este contexto lo real abordado por lo ficticio se convierte en espectáculo, en entretenimiento, en otras formas de recrear la memoria espacial y temporal de una comunidad. Pero ¿cómo se representa la percepción de la realidad?, ¿qué sucede cuando una persona que vive esa realidad trata de representarla en narrativas audiovisuales?, ¿cómo asume estas representaciones la sociedad dónde sucedió el hecho? Con estos interrogantes se inició esta investigación en la ciudad de Santo Domingo de los Colorados (Ecuador), donde circulan películas formato DVD de realizadores desconocidos en el contexto del cine nacional ecuatoriano. Las narrativas representan una realidad que ha sido lejana y negada por un grupo social con mayor capital económico, pero, una realidad cercana y cotidiana para un grupo de personas con recursos económicos limitados que sobreviven en la urbe mediante el comercio informal.

\section{Campo etnográfico}

La ciudad de Santo Domingo de los Colorados, ocupa una posición geográfica estratégica como puerto terrestre de intercambio comercial entre la costa y la sierra ecuatoriana. Sus dinámicas comerciales formales e informales han atraído a personas de toda la nación y de otros países vecinos, quienes buscan en este territorio una mejor oportunidad para sus vidas (TORRES EGAS; TORRES LÓPEZ, 2009). Esa configuración 
social de migrantes que llegaron en un principio sin recursos económicos con una bolsa llena de sueños y un cartón donde dormir, son el común denominador de algunas historias que vemos representadas por los productores informales en sus narrativas audiovisuales.

En esta ciudad, el tránsito social de inmigración ha aportado a los productores informales experiencias, historias y nuevas formas de entender el mundo. Por ello, desde una postura empírica, las nuevas narrativas audiovisuales se construyen bajo un "bricoleur" de lo que tenga el productor a mano, aprovechando el "conjunto de materiales heteróclitos" (LÉVI-STRAUSS, 1997, p. 36) que no están en relación con su rodaje, pero le ayudan a construir la representación, auto-representación y los modelos estereotipados de la industria hollywoodense (ADESOKAN, 2014).

Por otro lado, las mismas dinámicas sociales de esta cotidianidad masiva de lo urbano se manifiestan en formas discursivas, visuales y prácticas en la calle. Estás formas de percibir de los productores informales también pueden analizarse bajo los estados del capital cultural planteado por la teoría de Bourdieu, donde la incorporación está ligada al cuerpo del productor informal y se supone su incorporación, asimismo, el estado objetivado del capital cultural es transmisible "en soportes tales como escritos, pinturas, monumentos" (BOURDIEU, 2007b, p. 195-201). De este modo, al representarlo audiovisualmente con historias que generan identidad, despiertan sentimientos y visualizan espacios comunes, sus narrativas se convierten en nuevas formas de repensar, resignificar y recordar los sucesos que constituyen sus realidades.

\section{PRODUCTORES INFORMALES}

En el marco de esta investigación se seleccionaron dos productoras de la ciudad para la realización de esta etnografía. Los productores informales entrevistados son actores naturales no profesionales, que en un determinado momento de su ocupación laboral (formal o informal) decidieron poner un alto en su vida y darle rienda suelta a su imaginación, llevando a las narrativas audiovisuales las situaciones experimentadas, escuchadas, leídas en la prensa o vistas en televisión.

Los productores informales a partir de estas plataformas tratan de emular las narrativas cinematográficas con dispositivos domésticos, escenarios improvisados,

\footnotetext{
${ }^{2}$ Este término mantiene su vigencia en cuanto operador conceptual ya que considera las transformaciones dentro del cambio social y cultural "sin dejar de lado las limitaciones de las estructuras y tradiciones" (MÉLICE, 2009, p. 97).
} 
anotaciones que marcan la pauta de la acción mas no el diálogo. En cuanto al perfil, los productores informales son empíricos y ejercen varios oficios dentro del comercio informal y formal de la ciudad. En algunos casos, a duras penas, alcanzan un salario mínimo. ${ }^{3}$

Como pilar de sus producciones está la actuación intuida por un grupo de actores naturales, de manera que la narrativa y la ambientación dramática se tornan esenciales, aportando a la historia originalidad, fuerza y valor intrínseco. Desde esta representación subjetiva "la teoría más resueltamente objetivista debe integrar la representación que los agentes se hacen del mundo social y, más precisamente, su contribución de la visión de ese mundo" es aquí donde la representación de los productores impone su "propia visión del mundo o la visión de su propia posición en ese mundo, de su identidad social" (BOURDIEU, 1990, p. 287).

En otras investigaciones encontramos algunas convergencias en cuanto al perfil de algunos productores informales como son los "cineastas regionales" en Perú. Las coincidencias se presentan en sus labores informales dentro del comercio, los géneros fílmicos, y sus producciones de carácter empírico. No obstante, según Bustamante y Luna estos "suelen tener estudios técnicos o superiores en otras áreas como educación, derecho o ciencias sociales" (2014, p. 191). Además, postulan que muchos de los "cineastas regionales" han comenzado como actores y luego han incursionado como directores, guionistas, camarógrafos, sonidistas, entre otros trabajos.

La afinidad en cuanto a los perfiles de los productores informales no se presenta como un caso aislado y exclusivo de Santo Domingo de los Colorados. Encontramos en otros estudios como (Ecuador Bajo Tierra: videografías en circulación paralela) que en otras ciudades del país también se manifiestan este tipo de representaciones y autorepresentaciones audiovisuales bajo la dirección de productores no profesionales (ALVEAR; LEÓN, 2009). Asimismo, la similitud del perfil de los productores no profesionales se reproduce en países como Argentina, Brasil, Bolivia, Colombia, México, Nigeria, India, entre otros, "con las particulares propias del contexto del cual emergen" (VACA, 2015, p. 12).

\footnotetext{
${ }^{3}$ El productor informal "obra sin plan previo..." y al no ejecutar dicha obra con "materia prima, sino ya elaboradas, con fragmentos de obras, con sobras y trozos..." procede a realizarlo alejado de recursos, métodos y usos tecnológicos normales; actuando desde su conocimiento o experiencia "bricoleur” (LÉVI-STRAUSS, 1997, P. 35).
} 
En principio, para un productor informal no hay cámara, ni actores, solo breves anotaciones en una vieja libreta que cumple la tarea de guardar las ideas de sus historias. En este cuaderno de notas, en forma "bricoleur", estructura primero sus aspiraciones a guionista, donde esboza en breves anotaciones sus imágenes mentales, "imagen que se aproxima al recuerdo seleccionado que posteriormente reaparece en los relatos orales, como descripciones-interpretaciones" (RAPOSO, 2009).

En segunda instancia, aparece la concepción del género fílmico, donde el productor informal fórmula una explicación asistida por su imaginación, dando sentido a la trama, acción y el contexto de la historia. Ejemplo de ello es la representación de la superación social, la cual puede ser: psicológica, económica o educativa. Representaciones que se denominan en algunas entrevistas realizadas a los productores informales como "reflexiones" por el objeto de su mensaje.

En tercer lugar, se encuentra la participación actoral del mismo guionista y director, ya que se convierte en indispensable su participación como protagonista principal al ser el único que conoce en su totalidad la trama de la historia y los detalles más pequeños en cuanto al rodaje.

En el cuarto lugar, están las estrategias de comercialización, animadas en algunos casos por una red de socios que distribuyen de mano en mano las películas que sostienen los rodajes. En otro caso, está la autofinanciación del rodaje por parte del director, quien sale a vender por las calles su obra cinematográfica y cuando ya ha sacado su inversión la cede a las redes de distribución comercial pirata del país.

Esto me motivó a estudiar las percepciones, auto-representaciones y representaciones visuales que se construyen en los procesos de producción. Los cuales presentan esa "génesis social y una parte de los esquemas de percepción, pensamiento y de acción que son constitutivos” a los que Bourdieu llama habitus (BOURDIEU, 2007a, p. 127).

Para esta etnografía, propongo el término productor informal para identificar a la persona sin ninguna formación técnica en cinematografía, sin título académico, dedicada a oficios varios, que destina parte de su tiempo a recrear sus imaginarios cotidianos y situaciones vividas a través de narrativas audiovisuales en formato DVD con el fin de contar una historia y generar un ingreso económico extra para su hogar. 
Este trabajo se centra en recoger algunos aspectos de las experiencias en la preproducción, producción y postproducción realizadas por los productores informales en los contextos de rodaje. Este registro lo hago, luego de conocer parte de su cultura material, condición económica e historia de vida. La observación participante me ayudó a entender cómo estos aspectos influyen directamente en sus producciones. También me permitió examinar los procesos de realización en cuanto temáticas, estilos, escenarios y distribución comercial.

\section{La transfiguración de la venganza}

Las primeras narrativas audiovisuales de las productoras informales que seguí durante está etnografía, llevan en sus títulos la palabra venganza. Llama mi atención como esta palabra se repite anunciado el género fílmico de la acción en la película. Pensé de inmediato que la venganza puede ser imaginada y propuesta desde otras plataformas; y que mejor que estas sean creativas, expresivas y emocionalmente compartidas desde el lenguaje cinematográfico.

\section{La venganza de Cristóbal}

El productor informal Cristóbal Idilio Zambrano Vera, mejor conocido como Criszamver, nació en el recinto las Mercedes (Manabí), años más tarde se fue a vivir con su familia al territorio que se conoce como la Manga del Cura (Manabí). A los trece años se muda solo a Santo Domingo y vivió en las calles dedicándose a lustrar botas, lo que no le permitió terminar sus estudios de bachillerato. En su adolescencia se traslada a Quito, donde se dedicó al deporte alcanzando a ser representante de la provincia de Pichincha en atletismo, boxeo, fútbol y taekwondo. Además, fue jefe de cocina y administrador en un restaurante por cuatro años donde ganó mucho dinero.

Con el dinero ahorrado en Quito compró varias cabezas de ganado que puso bajo la administración de sus padres en la Manga del Cura. En esos años su hermano fue asesinado, circunstancia que causó calamidades y discusiones familiares, ya que la venganza era una vía para saldar lo ocurrido. Esto lo lleva a tomar la decisión de vender todo en la Manga del Cura e irse a trabajar y viajar por Sudamérica. A finales de los años noventa vuelve a Ecuador. El país pasaba por una profunda crisis económica, y como muchos ecuatorianos se sintió forzado a migrar terminando su periplo en España. En 2004 regresa al país, se radica en Santo Domingo y se dedica a vender artesanías en la calle. 
Cuando lo conocí a finales del año 2013 abandonaba el oficio de artesano. Me dijo que cumplía 45 años y había decidido dedicarse al oficio de productor audiovisual, artista, director, guionista y vendedor de sus propias producciones. Durante múltiples encuentros fue contándome diferentes historias de su vida. Dichas historias reposan anotadas en forma de guión en una pequeña libreta que conserva con mucho celo. Me dijo que conserva más de cuarenta guiones escritos y que cada uno pertenece a un momento de diversas situaciones ocurridas en la ciudad de Santo Domingo.

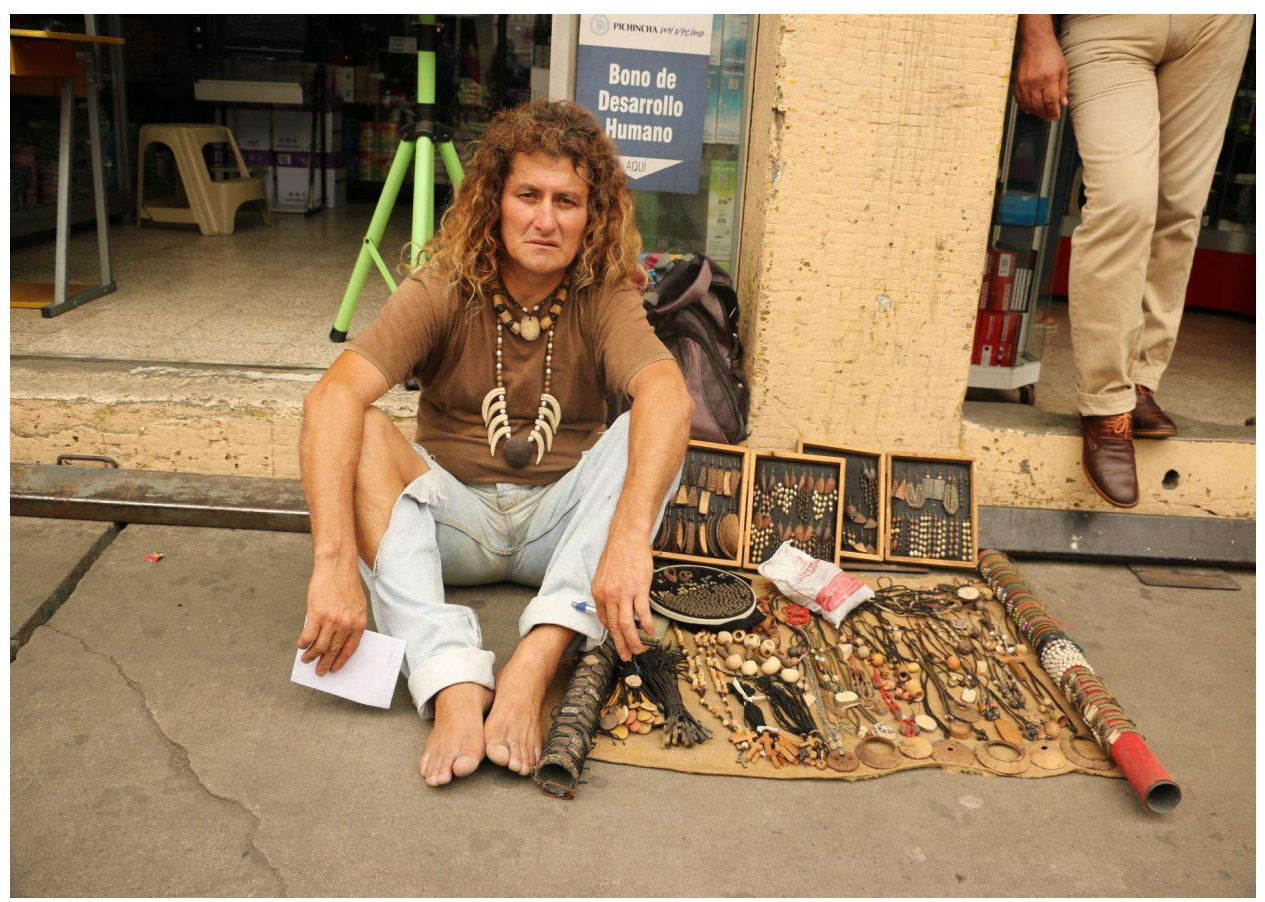

Gráfica 1: Criszamver en su puesto de artesanías, en Santo Domingo de los Colorados Fuente: archivo fotográfico del autor, 2013

Criszamver me invitó a la casa de Héctor Peña a un visionado de su nueva narrativa audiovisual. Héctor, es productor informal y fue el camarógrafo y editor de su nueva narrativa. La realización audiovisual titulada La Venganza de Cristóbal, ${ }^{4}$ cuenta la historia de un niño que vive feliz en la hacienda junto a sus padres. Un día dos malhechores interrumpen su cotidianidad y matan a su familia para quitarles la hacienda y robarles lo que tenían. El niño logra escaparse al bosque y queda recluido allí durante veinte años, viviendo como Tarzán con la naturaleza. Un día escucha gritos de una mujer en la selva en la cual vive y sale a su auxilio, encontrándose con una joven que ha sido secuestrada por

\footnotetext{
${ }^{4}$ Link de visualización https://www.youtube.com/watch? $\mathrm{v}=$ BtJfFOY011U\&t=54s
} 
varias personas. Para su gran sorpresa, dos de los secuestradores son los mismos que habían asesinado a sus padres.

Luego de una larga charla sobre la película, Criszamver queda pensativo y me cuenta que él había hecho la película por venganza y coraje. Sentía que tenía que subsanar la sensación de impotencia y frustración de hechos pasados. Además de ese sentimiento, esta película nace impulsada por el coraje que sentía hacia unas personas que lo habían humillado en producciones anteriores.

Esta transfiguración de la venganza convertida en una producción audiovisual como La Venganza de Cristóbal, según Criszamver alcanzó ventas mayores a dos mil copias en solo tres meses de circulación e impulsó su segunda obra. Este hecho motivó a otros productores informales quienes entre los años 2014-2015 estrenaron nuevas narrativas alcanzando ventas, que, a su vez, estimularon otras realizaciones.

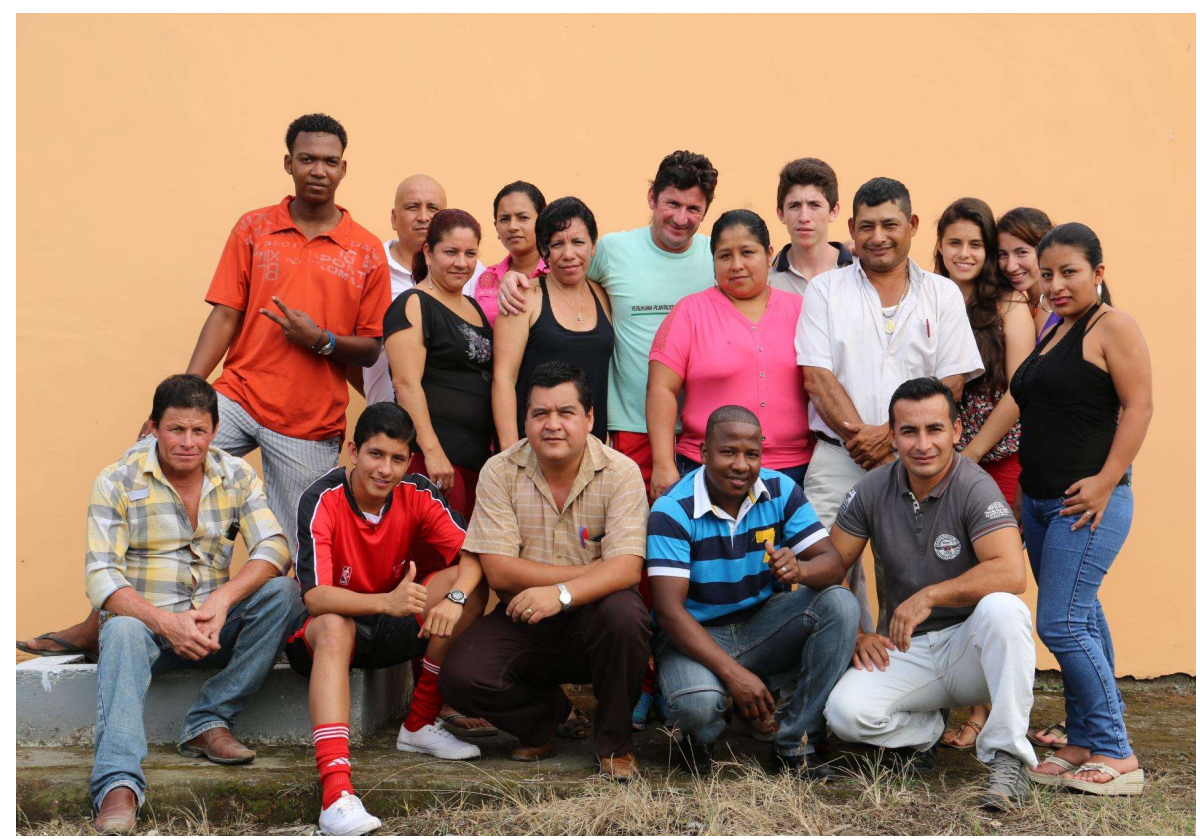

Gráfica 2: LED Producciones

Fuente: archivo fotográfico del autor, 2014

Líder Edison Loor Loor es el presidente de LED Producciones, la segunda productora que seguí durante la etnografía. Actualmente es vigilante y portero en una empresa. Tiene 45 años, bachiller, nació en el recinto Las Piedras (Manabí) y se radicó en Santo Domingo desde el año 2000 junto a su familia. En nuestra primera reunión fue acompañado con varios socios de LED Producciones. Ese día socialicé el interés de mi investigación, exponiendo cuál sería mi postura como etnógrafo en sus rodajes. Ellos me aceptaron con un gesto más de agradecimiento que de sorpresa, abriendo las puertas de su 
grupo con una bienvenida muy familiar. Me preguntaron si podía asesorarlos durante los rodajes, les contesté que podía ayudar (desde una posición técnica) para que no influyese tanto mi visión en sus narrativas.

$\mathrm{Al}$ segundo encuentro solo fue Líder, conversamos sobre su vida y su trabajo. Por seis años trabajó para una empresa en la cual sufrió un accidente perdiendo los dedos meñiques, medio e índice de su mano izquierda. Este accidente cambió por completo su vida. El seguro de la empresa lo jubila como persona discapacitada. Ese nuevo estado le dejó mucho tiempo libre. En ese tiempo conoce a un amigo dedicado a la pelea de gallos, quien le cuenta un hecho violento que sucedió en una gallera en Santo Domingo y lo animó a escribir algo sobre lo sucedido.

Líder, meses más tarde descubre que tiene facilidad para estructurar una historia como un guión cinematográfico. El amigo lo anima diciéndole que dispone de su apoyo para que realice una película. El nuevo libretista, sin tener idea de realización audiovisual asume el reto bajo una ávida emoción entre temor y valentía. Lo primero que hizo fue acreditar una cámara de vídeo digital, luego con la novedad de la cámara fueron apareciendo los actores, en su mayoría amigos y familiares, quienes no tenían ninguna experiencia frente a la videocámara, pero contaban con una disposición desbordante. Esta primera producción llamada La Venganza de los Galleros, marcó su camino. Durante la experiencia descubre que le gusta actuar, dirigir, cantar y editar. La realización se basa en hechos reales. Narra la historia de dos familias que se enfrentan por dinero, amor y placer. La venganza por medio de la muerte, delimita los territorios y fortalece el poder de una de las familias en la ciudad de Santo Domingo.

Líder me comentó que junto a sus socios decidieron realizar la segunda parte de la producción titulándola Secuestro por Venganza, ${ }^{5}$ cual narra la venganza de la familia desterrada. La cacería, el secuestro y el incendio del alojamiento de los agresores generan un enfrentamiento a muerte entre las dos familias. Esta segunda experiencia de rodaje les aporta confianza y solidez grupal. Decidiendo organizarse como una productora independiente LED Producciones. El ánimo grupal lleva a la producción en 2014 de Los Amores de David, ${ }^{6}$ realización mucho más ambiciosa. La producción trata sobre Pedro David, un empresario exitoso que sostiene con todos los lujos a su esposa Bárbara

\footnotetext{
${ }^{5}$ Link de visualización: https://www.youtube.com/watch? $\mathrm{v}=\mathrm{W} 4 \mathrm{NafaOAH} 8 \mathrm{c}$

${ }^{6}$ Link de visualización: https://www.youtube.com/watch? $\mathrm{v}=$ Bbb5qAI6yGY \& $\mathrm{t}=3 \mathrm{~s}$
} 
Santillán. En un accidente conoce a Jenny González, una joven muy atractiva de quien se enamoraría más adelante. La historia cambia cuando Bárbara descubre a Pedro David con Jenny y esta intenta asesinarla, impactando con una bala a Pedro David y dándolo por muerto. Está narrativa tuvo mucha acogida en el público familiar por ser un drama reflexivo.

Según los productores informales muchos de los hechos expuestos en sus narrativas audiovisuales representan una realidad experimentada social y personalmente. Los hechos que, para muchos ciudadanos, clase media alta, pueden presentarse ficticios o ajenos a sus cotidianidades no son aceptados en esta clase social. Por ello, el impacto y circulación de sus producciones tiene su mayor audiencia en los transeúntes cotidianos del comercio informal o, quienes tratan de sobrevivir cada día en la urbe, clase media y baja, ya que las producciones retratan situaciones violentas, de marginalidad y desigualdad que les son comunes. Es por esto que el uso del concepto de habitus planteado por Bourdieu permite entender y explicar la vinculación entre los hechos sociales y las experiencias percibidas y representadas por los productores informales.

\section{Hábitat y Habitus}

Criszamver y Líder nacen en la misma provincia, ambos llegaron a Santo Domingo en la misma situación laboral. Además, ambos provienen de una condición socioeconómica baja y limitada, arribando con los sueños y esperanza en que esta ciudad les brindara una oportunidad laboral. Criszamver pudo sobrevivir con sus artesanías muchos años, este fue conocido por diversos sobrenombres en la ciudad como "Hippie", "El Gitano", "El Mono", “Tarzán”, “Chaman” y "El Colorado” por sus diferentes atuendos para vender. "Mientras, Líder -conocido también como Colorado"-, se dedicó a labores bajo relación de servicios en diferentes empresas. Las dinámicas comerciales de la ciudad fueron ubicando a cada uno en actividades fortuitas dentro de los lugares que decidieron habitar (CAPDEVIELLE, 2011).

Estos lugares, de lo privado, lo íntimo, lo individual se convierte en espacio de reencuentro personal para los productores informales, de igual manera, ayudan a comprender el mundo representado en sus narrativas audiovisuales. Lugares representados con sistemas simbólicos que producen una correspondencia, según la teoría bourdieusiana, "entre las estructuras sociales y las estructuras mentales," estos espacios 
contribuyen esencialmente al producto de la incorporación de las estructuras objetivas del espacio social (2008, p. 36). Otra de las correspondencias se da "entre las divisiones objetivas del mundo social -particularmente en dominantes y dominados en los diversos campos- y los principios de visión y división que los agentes aplican" (BOURDIEU, 2007b, p. 133). Las correspondencias producen así una visión de mundo que no está exenta de las coacciones estructurales.

Es así como concebimos las normas impuestas por la sociedad en que vivimos. De acuerdo con profesora Claudia Zamorano, el hábitat hace referencia a "las prácticas y representaciones" que permiten el desarrollo de un sujeto ubicarse "dentro del orden espaciotemporal" creando con el ambiente una relación íntima (2014, p. 282). Pero ¿qué pasa cuándo queremos compartir esta intimidad? ¿Cuándo nuestros pensamientos desean develar lo que somos y cómo lo vivimos dentro de estos espacios? Estos interrogantes surgen por la constante auto-representación que hacen los productores informales de sus hogares y espacios laborales en las películas.

Criszamver define su hábitat como un museo. Sobre el umbral de su casa cuelga un pedazo de madera color rojo que anuncia el nombre "Rancho el Descanso" con letras pintadas en blanco. En ella encontramos un museo de su propia vida. En esta actividad "bricoleur" "cada elemento representa un conjunto de relaciones a la vez, concretas y virtuales; son operadores, pero utilizables con vistas a operaciones cualquiera en el seno de un tipo" (LÉVI-STRAUSS, 1997, p. 37). Él mantiene una exposición de materiales heteróclitos permanente sobre todas sus historias y aventuras, además sobre su cosmovisión del mundo. Exposición que permite construir una idea de sus pensamientos hacia el mundo y su interacción con éste. En toda la pared y el techo cuelgan prendas de vestir, armas de fuego, utensilios de cocina, bicicletas, lanzas de pambil, arcos, flechas, botellas, piedras, semillas de colores, raíces de árboles fosilizados y una serie de fotografías que narran desde su infancia hasta el artista que es hoy. En el centro de la casa tiene seis mesas con sus bancos de madera y sombrillas de paja, a cada lado de estas mesas se encuentra árboles frutales con una inscripción sobre cuidar la naturaleza y una hamaca de caña guadua.

La explicación de los utensilios de toda la exposición dura alrededor de cincuenta minutos. Este espacio cuenta con una sola habitación en madera de dos por dos metros 
que es su dormitorio. Un pozo profundo donde obtiene el agua, un baño y cocina improvisada.

Criszamver mantiene su casa como futuro proyecto de museo y sala de proyecciones al aire libre. Piensa que como primer museo de la ciudad pronto vendrán muchas personas a visitarlo, así tendrá la posibilidad de brindar servicios gastronómicos y proyectar sus películas. Su postura ante la vida siempre ha sido la visión de la libertad y realizar sus sueños. La pasión por hacer películas la define como una respuesta contestataria de coraje a la imposibilidad o dificultad que muchos profesionales encuentran a la hora de realizar un proyecto audiovisual.

Este lugar permite ver elementos detonadores de su memoria y la realidad que lo circunda. ${ }^{7}$ Los instrumentos cuentan historias de circunstancias experimentadas, recrean contextos que luego lo vemos reflejados en sus películas como: Juegos del Destino (2013), Venganza de Cristóbal(2014), Criszamver (2015), Criszamver 2, (2016).

Por otra parte, el contexto familiar de Líder es tradicional. Él vive con su esposa y sus cuatro hijos. En nuestra primera conversación, antes de conocer su casa, Líder dejó claro quién sostenía el hogar, dicho pronunciamiento establecía el rol de su esposa como ama de hogar. Esta sentencia determinó mi mirada sobre su hábitat. Dato que evidencia la posición de los materiales de trabajo que privilegian la distribución en su hábitat familiar. En la sala de su casa tiene un equipo musical de gran potencia que utiliza para amenizar las fiestas que contrata (también es cantautor y animador de fiestas), un televisor conectado a un reproductor de DVD y quince películas. Tiene una habitación especial para editar audio y vídeo, dos habitaciones más para sus hijos y su esposa y un espacio amplio para cocinar.

Esta ideología es coherente frente a la representación que él hace de la familia en su narrativa audiovisual Los Amores de David(2015). Líder me cuenta que en esta película retrata parte de su vida, ya que su esposa es tan celosa que podría llegar a matar a quien trate de interponerse en sus caminos sentimentales.

\footnotetext{
${ }^{7}$ En el documental "O fio da memória (1991)" del director brasilero Eduardo Coutinho, vemos cómo se construye un tipo de narrativas que evoca el pasado del Sr. Gabriel Joaquim dos Santos. En comparación a Criszamver, Gabriel también activa sus mecanismos de memoria presentado sus recuerdos en forma fragmentada y sin organización. Echando mano de lo que tiene o puede disponer, estimulando el "bricoleur" que dispone en materia a su propia historia. Tanto en Criszamver como en Gabriel, podemos encontrar hechos materiales que representan planos de conocimientos unilaterales como la Casa de las Flores y el Rancho el Descanso que los hacen hombres excepcionales.
} 
Estos aspectos contextuales, materiales, culturales y sociales van arrojando detalles del complejo tejido perceptivo, ideológico, representacional de sus vidas. El hábitat del que hablamos genera distintas prácticas que van sucediéndose distintamente en contextos diversos a partir de su experiencia "bricoleur". Este hábitat moldea el habitus bourdieusiano de "experiencias pasadas" catalizando acciones, sistemas de disposiciones, estructuras que integran percepciones que, sin lugar a dudas, potencian las representaciones dadas por los realizadores audiovisuales. El habitus como potenciador social confiere experiencias previas, estableciendo la capacidad de diferenciar el mundo social representa "lo bueno lo malo, lo vulgar, lo distinguido". Sistemáticamente produce prácticas que conllevan acciones individuales y colectivas asegurando experiencias, historias, actuaciones de inmanencias pasadas (CAPDEVIELLE, 2011).

Desde la diferencia, los habitus auto-representacionales de estos dos productores nos permiten adentrarnos audiovisualmente a un Santo Domingo desconocido para muchos habitantes locales. Sus miradas, sus posiciones socioeconómicas, sus situaciones familiares, Líder casado con un enfoque tradicional del rol matrimonial y Criszamver soltero y su visión liberal de aventurarse a la vida. Ellos perciben la realidad desde sus propias experiencias, construyendo universos paralelos que transmiten mensajes de representaciones ajustadas a sus imaginarios y sus diversas fuentes de información.

Las fuentes que más alimentan sus imaginarios es la información que circula por las calles de la ciudad en forma oral. Sus portavoces exageran los hechos creando tensión narrativa y generando mayor impacto al receptor. También se nutren de la prensa escrita local y los noticieros de televisión.

Por ende, su habitus se presenta como sistemas generadores y organizadores de experiencias y representaciones que se ajustan objetivamente a sistemas "reguladas y regulares sin ser el producto de la obediencia a reglas, y, a la vez que todo esto, colectivamente orquestadas sin ser el producto de la acción organizadora de un director de orquesta" (BOURDIEU, 1991, p. 92).

\section{Percepciones encontradas}

Durante esta investigación traté de hablar sobre las narrativas audiovisuales de productores informales con los diferentes directores culturales del área pública de la ciudad. Sus manifestaciones fueron unívocas, "estas producciones no representan la 
realidad de la ciudad". Este comentario se generó luego del estreno en el 2015 de la película "Rosario" del director local Luis Ángel Carvajal, la cual contó con apoyo de varios entes gubernamentales. La producción trató sobre la prostitución en la ciudad. El problema estaba en los contextos donde se desarrolló el rodaje. La producción representaba el trabajo sexual, la venta de alcohol y los focos de delincuencia en lugares cercanos a la administración municipal tales como la calle peatonal, el parque Zaracay, entre otros exteriores del municipio.

Durante una conversación con el director Luis Ángel Carvajal declaró que su objetivo era generar conciencia sobre esta problemática en la ciudad. El tema no era solo de crear zonas de tolerancia "sino ejercer el oficio de la prostitución en forma digna". Ya que es una realidad local que el estado no puede tratar violentamente. Por su parte, Líder me comentó que él había asistido al lanzamiento. Su desacuerdo estaba en las palabras salidas de tono, en la constante escenas sexuales y algunos personajes que no consideraría aptos como artistas para sus películas, como los transexuales, homosexuales, drogadictos, ladrones y alcohólicos que en consecuencia son auto-representaciones directas en el contexto de esta narrativa audiovisual. Líder terminó declarando que respetaba la obra del compañero.

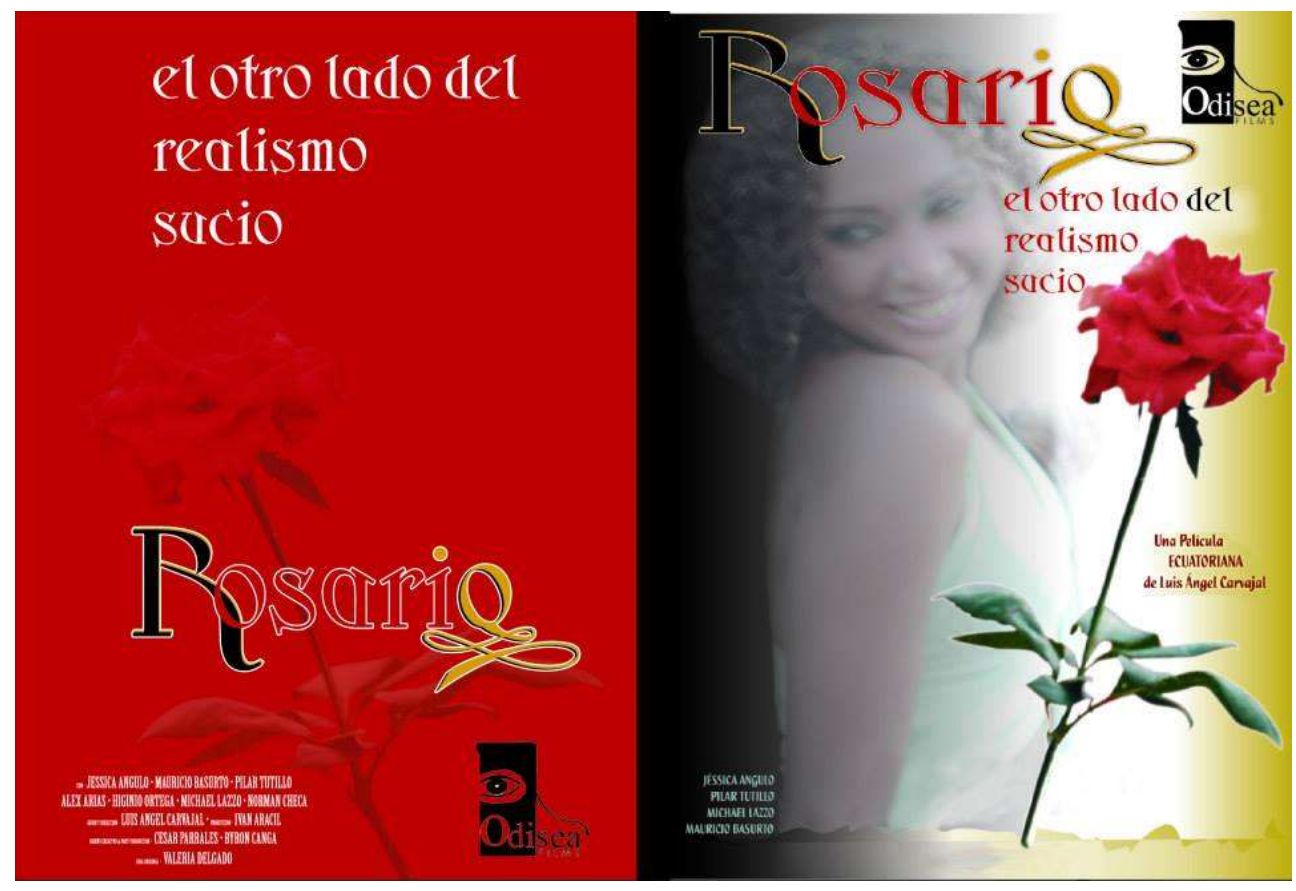

Gráfica 3: portada película Rosario

Fuente: archivo fotográfico del autor, 2015 
En cambio, Criszamver me comentó que le sorprendió la presencia del Alcalde en el acto de lanzamiento de dicha película, quien luego de las fotografías y las palabras de lanzamiento se levanta en plena función y les dice a los técnicos que detengan la proyección porque la violencia y las imágenes de la película hacen quedar mal a la ciudad y no aportan nada educativo, ni valorativo a la audiencia. Para él, la película no fue tan fuerte y exaltó que se haya tenido en cuenta a algunos personajes de la cotidianidad nocturna de la ciudad.

La película luego fue estrenada en salas de cine comerciales. El rumor de las escenas fuertes, de la participación de algunos personajes reales de la vida nocturna generó expectativas y una buena acogida en las salas de cine de la región. Abordé a algunos espectadores, sus comentarios no fueron positivos ya que ellos esperaban más escenas de sexo y acción. En cuanto al mensaje y a la representación hecha de la ciudad, se sintieron ajenos ya que poco habitan esa zona de la ciudad por considerarla peligrosa. Mi pregunta de inmediato fue ¿qué consideraban peligroso, el lugar, las personas que transitan o habitan la zona? Sus respuestas fueron contundentes al decir "todo".

Santo Domingo de los Colorados es conocido en todo el país como la ciudad del placer. El negocio de los "night club" es próspero. Uno de sus atractivos turísticos nocturnos es hacer un tour por la "vía del placer". La vía que conduce a la ciudad de Quevedo alberga en tan solo siete kilómetros y medio, más de diez salones para adultos de todos los extractos sociales. Sus nombres son un tanto dicientes: La Luna, Dos y Medio, La Casa de las Muñecas, El Harén del Puma, Harén, Viña Cariño, Las Flores, el Kapital, Son de Cali, Casa Blanca entre otros. Dentro de la ciudad existen desde los más exclusivos como 5-15, hasta los de servicio callejero, de los cuales hace referencia la película "Rosario".

Criszamver, en una de nuestras entrevistas, me pidió que fuese a un "night club" con él. Me comentó que su próximo rodaje se desarrollaría en ese lugar. Me dijo lo siguiente: "Mi próxima película tratará sobre un secuestro de una joven del pueblo que fue mi novia y nos íbamos a casar. Unos malhechores la llevan a la ciudad y la ponen a trabajar como prostituta por su belleza virginal. Y es aquí donde entra Criszamver a rescatarla y vengarse de todos" (Conversación, 16/9/2016).

Me cuenta que la historia está inspirada en un hecho real de unas jóvenes que fueron víctimas de la trata de blanca en la Manga del Cura, y que ellas hoy en día viven de 
ese oficio en España. Criszamver transfiere sus experiencias del campo a la ciudad, pero con la percepción del redentor, vengador, héroe, aquel que devuelve la esperanza y la ilusión de justicia social.

Acudimos una noche al lugar donde él ya era cliente asiduo. Pedimos una mesa y conversamos con el administrador del "night club". Éste le dijo que no había ningún problema, que lo único que pedía era evitar nombres y actos que comprometa la integridad y el buen nombre del lugar. Criszamver se comprometió con lo requerido y le dijo que le avisaría el día de la escena. Acto seguido pidió dos cervezas y llamó a una afrodescendiente que ya conocía. Cuando se le acercó me dijo: "viste, así es que tienes que grabarme feliz con mi chica y soltó una carcajada”. Yo asentí con mi cabeza y dibujé una sonrisa en mi cara de asustado preguntándome sobre la coherencia entre su comportamiento en ese momento y su futura realización audiovisual.

La práctica representacional se expresa también en el cuerpo de los productores informales y de las personas con las que interactúan. Durante la socialización se transfieren e incorporan las "estructuras inmanentes" de un mundo. Para Pierre Bourdieu el cuerpo "modelado por las estructuras sociales y mentales es un cuerpo socializabilizado, estructurado, que se ha incorporado a las estructuras inherentes donde se interiorizan los esquemas del habitus". El cuerpo de los productores, las personas con las que interactúan y audiencia es moldeado y condicionado por sus restricciones materiales, económicas y culturales. Los moldes y limitaciones generan conductas y disposiciones, por ende, el aprendizaje no se presenta como un comprender, sino que se incorporar mediante la experiencia y se introduce en el cuerpo. La práctica, entonces, garantiza una comprensión del mundo distinta al "desciframiento consciente" (1999, p. 180-182).

\section{MEMORIA DE LO INVISIBLE}

Como vemos, la experiencia de Criszamver, Líder enmarcan una serie de circunstancias para entender la ciudad desde otras representaciones visuales. Ellos no tratan de criminalizarla, tratan de mostrarla como la perciben, claro, utilizando la ficción, representando el lugar donde viven. Se podría pensar que los productores informales se determinan: "Sólo en la medida en que se determinan a sí mismos. Pero las categorías de percepción y apreciación que proporciona el principio de esta (auto)determinación están 
a su vez ampliamente determinadas por las condiciones sociales y económicas de su constitución” (BOURDIEU; WACQUANT, 2008, p. 177).

Por ello, sus producciones evocan una ciudad que para muchos es invisible, ajena, negada, en tanto para ellos es simplemente real. El estar allí, en ese campo invisible pero presente, les permite narrar a través de imágenes en movimiento. Convirtiéndolos en recreadores de sus propios contextos que son ampliados por sus condiciones materiales, biográficas y económicas, por donde:

La representación de la diferencia deberá entenderse, por lo tanto, como el, resultado de un proceso de clasificación social y culturalmente determinado que en última instancia nos habla más de cómo una comunidad entiende el mundo que de la realidad intrínseca de éste. De este modo, el interés de una clasificación dependerá más que de aquello que se nos muestra, de lo que deliberadamente está ausente (GUARNÉ, 2004, p. 47).

El producto audiovisual como esa realidad intrínseca representada es el objeto mismo de lo que se niega, se esconde, se invisibiliza socialmente, ejemplo de ello es la violencia, el secuestro, la desigualdad social, los lugares y personas que son señaladas injustamente como peligrosas entre otras situaciones representadas en las narrativas audiovisuales. Lo que el productor informal entiende como realidad, se presenta entonces como posible memoria colectiva a partir de su narración ficcional. Y allí está el objeto: el marco mismo de la realidad representada. La función y proceso en recrear audiovisualmente los hechos sociales se convierten en testimonio y memoria cultural. La experiencia de los productores audiovisuales resalta el valor intrínseco representado culturalmente.

Según los mismos productores informales sus narrativas audiovisuales se han visto marcadas socialmente por la condición socioeconómica que representan. Por ello, sus actuaciones, expresiones, vestimentas y presencias, son estereotipadas como inferior, vulgar y popular por aquellos que no se sienten representados en las narrativas audiovisuales. Desde lo subalterno como fuerza de resistencia hacia los señalamientos "se manifiesta, entonces, la periferia, la miseria y los márgenes que devienen en la suerte de “centro silente o silencioso” del que habla Gayatri Spivak” (SILVA., 2006, p. 47). 
Las relaciones que se establecen socialmente entre las jerárquicas del poder, frente a lo subalterno demarcan fronteras entre lo privado y el sujeto que habita la calle, lo público, lo informal. Todo aquello que se representa audiovisualmente en sus narrativas como lenguaje corporal, dialecto, tono de voz, vestido, diálogo, mensaje, ambiente, imagen, contextos, hábitat, habitus, manifiesta esa mirada lejana, extraña, negada y ajena que expone la jerarquía.

Las producciones de Criszamver y Líder, no buscan desdibujar, deconstruir, combatir el imaginario social estereotipado que puedan salir de sus narrativas. Son conscientes que sus películas emulan los estereotipos hollywoodenses, en donde el héroe nunca muere, convirtiéndose en justiciero social, en el cual, la moral guía conscientemente sus actos éticos y sociales. Estás narrativas audiovisuales se convierten en conducto de expresión, manifestando espacios y tiempos que están fuera de algunas clases sociales dentro de la ciudad. Ellos capturan con sus lentes una cotidianidad invisible cargada simbólicamente de contextos que otros transeúntes que habitan la calle consideran peligrosas. Sus narrativas observan en cada captura una realidad que se sucede constantemente. Y esta representación es, a su vez, lo invisible. El estar allí, el realizarse allí, configura su presencia que pasa inadvertida para el otro que mira y habita lo cotidiano.

Una ciudad no se hace sola, se construye a diario; y si queremos entenderla, debemos hacerlo desde las diversas expresiones que se dan en ella (OBRADORS, 2005). La prensa, el comercio formal e informal, el transporte, los transeúntes, entre otras dinámicas marcan espacios y tiempos sociales, creando imaginarios colectivos. Estos aspectos guían cualquier análisis que se quiera hacer de ella. La prensa anuncia hechos violentos e inseguridad a diario. El comercio formal e informal dinamiza diversas economías. El transporte público y privado en el centro de las ciudades deviene los comportamientos de los transeúntes y fragmenta contextos. Las ciudades nos las imaginamos e inventamos a diario. Es lo que Benedict Anderson ha denominado cómo comunidades imaginadas (1993), y es ese imaginario el que representan las realizaciones audiovisuales de los productores informales.

Durante esta etnografía identifiqué temas recurrentes en diversas conversaciones con Criszamver, Líder, Héctor Peña, Ángel Carvajal y otros actores y productores audiovisuales. Criszamver siempre habló sobre la justicia, la responsabilidad, la camaradería que lo rodea y caracteriza. Sus sueños son viajar a México y de allí Hollywood 
para realizar una película con Danny Trejo (actor estadounidense de origen mexicano de nombre artístico "Machete”). Mientras que para Líder la reflexión es importante, dar ejemplo sobre la moral, la fidelidad, el amor a la familia y a Dios. El sueño que constantemente expresaba, pensativo, era llevar una de sus películas a cualquier sala de cine comercial.

\section{El lugar auto-representado}

Abordar a las narrativas audiovisuales en sus procesos de realización requiere de una amplia mirada en sus contextos de preproducción, producción, posproducción. Las particularidades de estas obras se encuentran en los productores informales que fortalecen los lugares auto-representados con su actuación intuida, sus escenas improvisadas y el aprovechamiento de espacios y tiempo representativos socialmente. A continuación, abordaré algunos aspectos importantes durante estos tres momentos de producción.

- Preproducción, locaciones y género fílmico: nuestras percepciones están modeladas por diversas circunstancias ambientales, biológicas y culturales. La memoria deviene cual "bricoleur" a nuestra cultura material. Por ejemplo: el contexto socioambiental y económico donde crecieron Criszamver y Líder, está marcado por su cultura material y la naturaleza. Ambos migran del campo a la ciudad, abandonando sus familias, buscando mejorar sus vidas en todos los aspectos. Por diversas circunstancias sus caminos son totalmente diferentes. Criszamver decide no tener familia y aventurarse a la vida del día a día laborando en el comercio informal. Líder construye una familia y busca trabajos formales bajo relación de servicio. Estos aspectos se reflejan en sus guiones y sus géneros fílmicos, y también determinan su hábitat y habitus.

Las locaciones en sus narrativas audiovisuales son en consecuencia las siguientes: en la película Criszamver 2. El rodaje se produjo entre Santo Domingo y La Manga del Cura, donde se rodó gran parte de la película. Los contextos de grabación son lugares llenos de historias violentas, de personajes prófugos de la justicia por ajustes de cuentas o venganza. La primera muerte en esta narrativa se produce en un camino lastrado. Criszamver se enfrentaba a su primer enemigo llamado "El Diablo".

Allí, en el lugar de la escena, han sucedido múltiples asesinatos por diferentes motivos, entre ellos el de su hermano. La secuencia de esta escena es improvisada, todos aportábamos comentarios para darle fuerza a la acción. Lo único que no se improvisó fue el escenario, Criszamver ya lo había escogido con anterioridad, puesto que este es 
representativo para los espectadores de sus producciones al ser lugares llenos de historias. Aquí entra la temática y el género acción.

Las locaciones de Líder, en Los Amores de David son más urbanas. Buscan representar esa ciudad de clase media alta. Restaurante de lujo, prósperas empresas, mansiones, clínicas privadas, servicio doméstico, autos de alta gama, vestidos costosos y lugares exclusivos de diversión.

Aquí, entra la temática y el género dramático de sus narrativas audiovisuales. El engaño visto como aberración social se convierte en detonador de violencia fatal. Los celos, la mentira, la codicia, la lujuria se exponen trágicamente desde una moral que carece de conciencia ética. Líder denomina estás producciones como un mensaje de reflexión social. Ambas producciones escenifican sus percepciones temáticas y representan esa cultura material que han experimentado, instituido y adquirido, desde sus propios espacios.

- Producción: la actuación intuida, es decir, actores naturales de poca experiencia, escenas improvisadas, el aprovechamiento de espacios y tiempos entre otros factores, dan vida al drama. La mayoría de artistas en la película de Criszamver son ocasionales. Colaboradores por antonomasia que por primera vez actúan frente a una cámara. Por tal motivo el guión se reescribe con los nuevos aportes en cada improvisación. Otra de las cualidades de estos artistas es la disposición material en cuanto vestuario, utilería, maquillaje, logística, espacios y tiempos. Estos facilitan, sus autos, sus casas, disponiendo el tiempo que sea necesario para lograr una escena. Se acostumbran con facilidad a las agotadoras repeticiones de las escenas por las múltiples equivocaciones.

Durante el rodaje de una escena peligrosa hubo tensión por parte de los familiares y amigos de Criszamver. El acto consistía en saltar de cabeza a una cascada del río " $E I$ Pintado" conocida como "El Salto del Armadillo". Este torrente de agua es un lugar turístico de la región y respetado por las diversas muertes que ha causado a muchos osados en desafiarlo. Criszamver, era consciente que podría morir ahogado o impactar su cabeza con alguna roca en el fondo del pozo; pero también sabía que si lo lograba quedaría como un valiente y dejaría registro de su proeza en la producción. La escena tuvo muchos espectadores al conocer que se lanzaría de 12 metros de alto con vestimenta no adecuada (botas militares, un puñal de 7 pulgadas en hoja metálica y una empuñadura de hierro). 


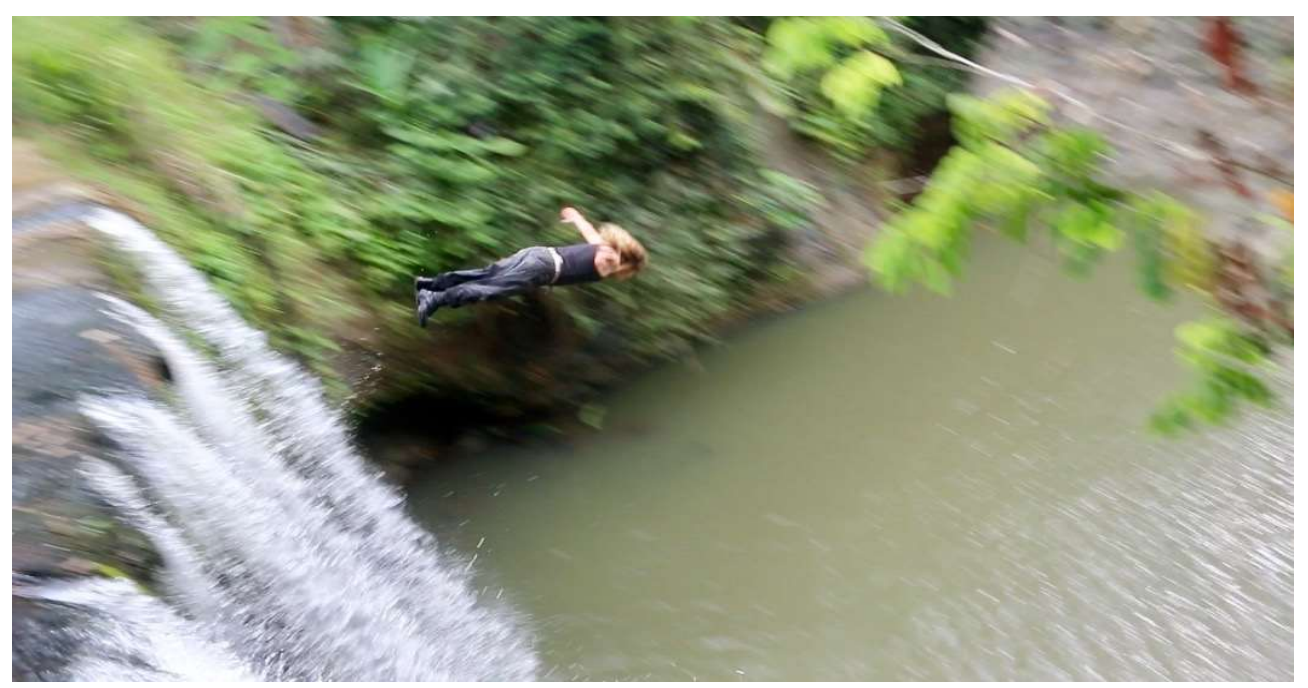

Gráfica 4: rodaje

Fuente: archivo fotográfico del autor, 2016

Animado decía: "Rambo saltó de tres metros yo lo superaré con 9 metros más alto". Me dijo; "hazme la toma desde arriba, vas a ver cómo lo logró."Su caída fue perfecta, su cabeza entró y salió velozmente del agua, comenzando a nadar rápidamente hacia a la orilla. Cuando salió los espectadores lo felicitaron y él se sentía poderoso, podría vérsele el rostro lleno de alegría.

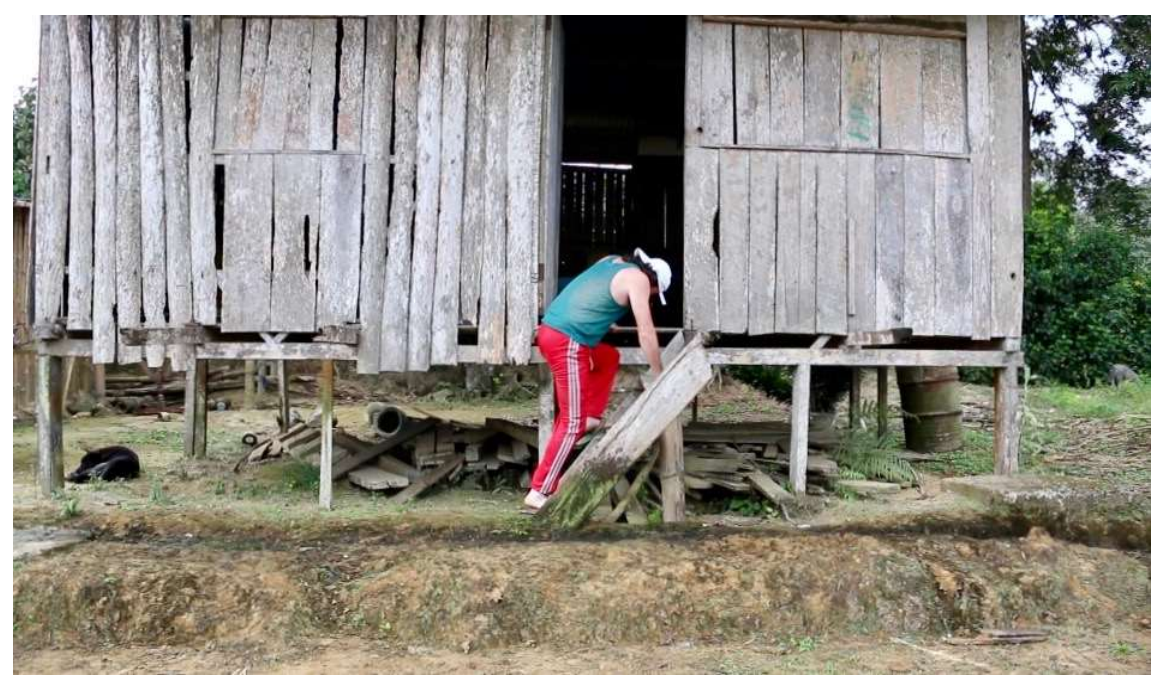

Gráfica 5: rodaje

Fuente: archivo fotográfico del autor, 2014

La producción de Líder es más organizada. Con sus socios ensaya con frecuencia cada escena. Aunque también son actores naturales, en su mayoría las equivocaciones durante las escenas son porque no se aprenden el guión. Líder como director deja poco a la improvisación, no realiza escenas de gran riesgo. Esta asociación dispone de una red de amigos que gestionan lugares y colaboran económicamente para comprar utilería, 
maquillaje, vestidos, arrendar transporte entre otros gastos. La escena más peligrosa fue rodada en un barrio popular llamado "La Cadena" conocido en la ciudad por el expendio de drogas y la delincuencia.

Allí, se realizó la toma donde Pedro David se refugió luego que Bárbara le hubiese propinado el balazo en el restaurante. La escena se desarrolló en una casa de tablas que crujían y se movían al caminar sobre ellas. Líder aprovechó unas escaleras e improvisó una nueva escena donde su personaje caería al tratar de bajar unas escaleras de maderas podridas y resbalando estruendosamente a la calle gritando del dolor que lo ayuden. Cuarenta minutos más tarde terminó la escena, Líder nos manifestó que se había golpeado con fuerza el dorso y que sentía molestias, pero seguiría la grabación.

Para Criszamver un rodaje se puede hacer en un mes. Para Líder, toma hasta un año. Ambos se exponen a que el éxito o el fracaso marquen sus producciones. El primero por aquello de las repentinas improvisaciones. El segundo porque en medio de la película un protagonista se vaya a otra ciudad por diversas razones y deje inconcluso su personaje.

El hábitat y habitus influye en sus procesos de producción, permitiendo apreciar las marcadas diferencias en las formas de rodar una película entre Líder y Criszamver. El primero es muy ordenado y siempre actúa bajo la guía de su libreto, solo acepta aportes de sus artistas cuando observa que la escena cae en un sesgo por una limitada interpretación por parte de un actor. Es aquí cuando se manifiesta ese habitus del orden que ejerce en su trabajo de guardia y portería y aquel poder de mando demostrado en su hogar. El segundo innova el diálogo en la escena, y si esta se presta, permite que sus artistas propongan contenidos de más acción y suspenso. Por ello, el habitus de Criszamver es ligero formado en la cotidianidad impredecible de la calle y la aventura. A la hora de rodar escenas peligrosas Criszamver puede arriesgar hasta su propia vida. No es que presente un desarraigo de su hábitat, sino que la entiende (según él) como parte esencial de su ser. Líder prefiere no asumir riesgos, pero dado el caso de peligro opta que su personaje lo asuma. El control del hábitat para él es importante. Frente a la percepción de la realidad del hábitat y habitus sus ideas, argumentos, posturas guardan una semejanza considerable. Aunque discrepen en las formas de presentar la realidad, Líder prefiere que haya pocos muertos en sus producciones, mientras que en las películas de Criszamver los muertos hacen parte fundamental de la acción. En síntesis, el habitus para Criszamver y Líder se presenta como esa suerte de sentido experimental de lo que debe hacerse en determinadas situaciones. 
- Postproducción y ocupaciones diversas: mientras que Criszamver maneja tiempos de rodaje consecuentes por su actividad laboral informal y el ir interactuando con personajes improvisados en cada escena. Líder y su asociación se reúnen los domingos para cada rodaje. Los miembros tienen diversos oficios son ama de casa, taxista, vendedor ambulante, albañiles, cantante, estudiante, entre los ocasionales como un médico, abogado y policías.

Por esa razón el trabajo de edición es más un oficio especializado. Criszamver lo realiza con Héctor Peña, estos editan durante un mes consecutivo hasta tener el producto final. Si es necesario hacer más escenas para darle más fuerza o coherencia a la trama no se complica y las realiza. Mientras Líder edita construyendo secuencias por bloques y luego las lleva donde Peña para pulir y agregar efectos especiales. Héctor Peña, cuando no consigue el sonido deseado de un grito o una queja humana lo produce sonoramente con su voz. Héctor, se convierte en pieza clave a la hora de terminar las películas, por sus conocimientos en edición, color, sonidos, musicalización y efectos especiales.

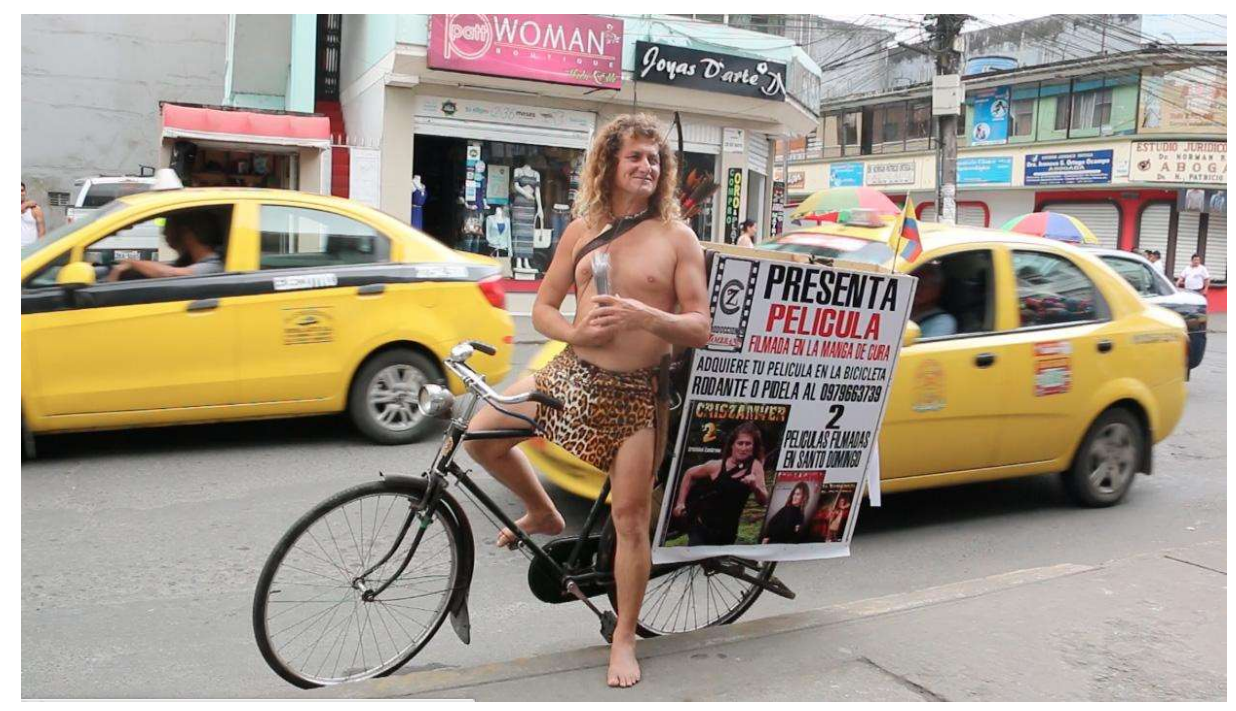

Gráfica 6: comercialización.

Fuente: archivo fotográfico del autor, 2016

Durante la comercialización Criszamver echa mano de todos sus conocimientos en ventas. Reproduce las portadas de las películas en dos lonas publicitarias de 70 x 50 y con ellas arma una especie de caja en madera y la sube en la parte trasera de su bicicleta. Como sabe que a los niños les gusta su personaje anterior que emula a Tarzán, sale manejando su bicicleta por el centro de la ciudad vestido con un taparrabo y un collar que sostiene como dije un colmillo de un felino. Esto causa impresión y extrañeza en medio del ajetreado 
comercio en los transeúntes. El primer día de ventas de la producción Criszamver 2, lo acompañé durante su comercialización y vendió sesenta películas a dos dólares cada una. Durante este trabajo muchas personas lo abordan felicitándolo y animando a que siga haciendo más películas.

Líder por su parte comercializa sus películas por encargo. Sus ventas son más direccionadas a personas que conoce durante la producción, familiares amigos. Sus socios se encargan de comprar en grandes cantidades a precios módicos para luego distribuirlas en sus medios. Estos casos de producción audiovisual se presentan como una nueva forma de narrar la cotidianidad e intervenir lo comercial desde el mismo productor informal. Acciones que permiten el reencuentro entre la percepción subjetiva y la percepción general.

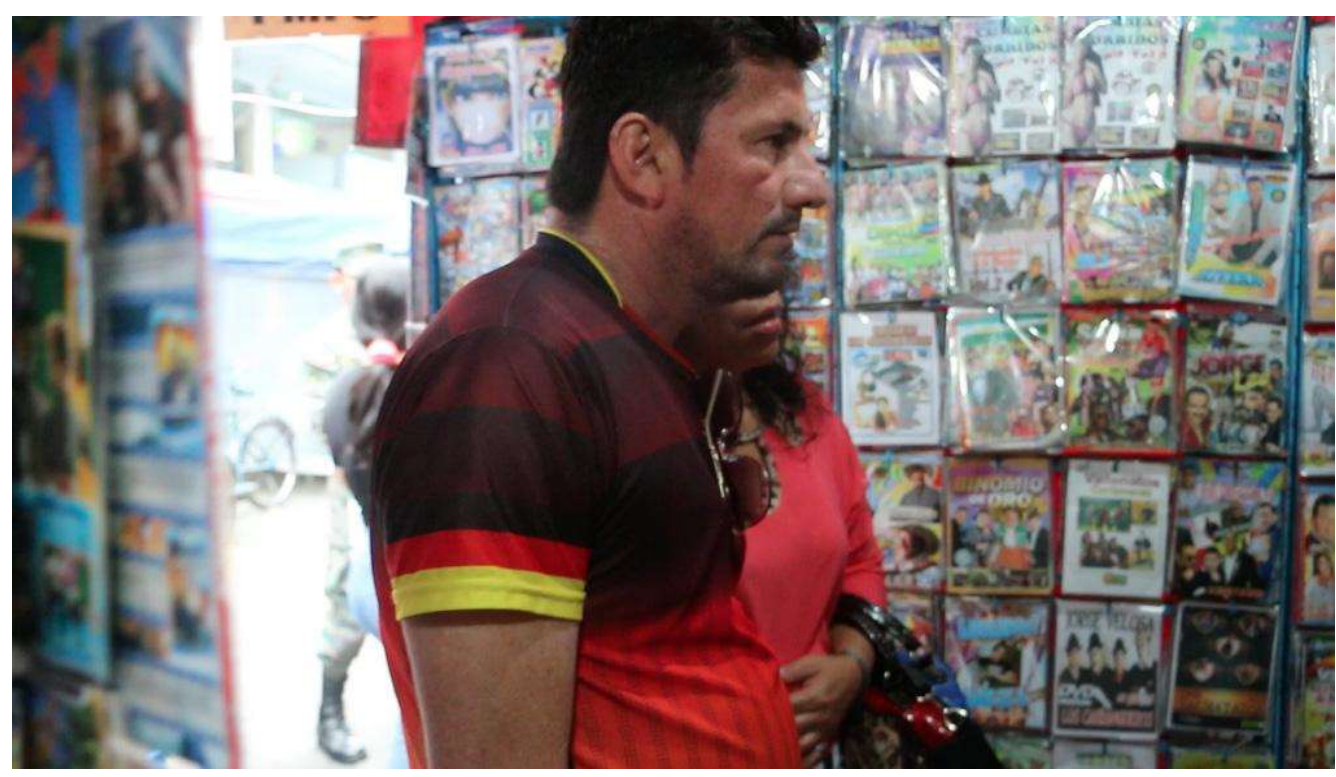

Gráfica 7: comercialización

Fuente: archivo fotográfico del autor, 2016

Los productores informales, muestran sus cotidianidades y sus contextos desde una perspectiva que media, construye y genera otras miradas que busca narrar esa otra ciudad. El acercamiento de la antropología audiovisual en la práctica no debería ser desde el extrañamiento mismo del hecho o sujeto en sí, sino al estudio de lo cotidiano de ese hábitat y habitus que nos rodea.

\section{Reflexiones finales}

La antropología audiovisual esta llamada a elaborar nuevas categorías de análisis para pensar las rupturas y cambios que se presentan en el entorno variante y discursivo 
que deviene del sujeto. Como lo propusieron Jean Rouch y Edgar Morín en Crónicas de un Verano 1961. Ya que el dispositivo audiovisual, la cámara con la que observamos permite repensar los espacios desde diferentes enfoques investigativos. El concepto de habitus permitió consolidar puntos de análisis sólidos a la hora de entender explicar y comprender las percepciones de los productores informales. Estos puntos nos ayudan a entender, identificar, pensar, analizar los contextos o entornos que presenta la vida de un sujeto, y lo que este construye entre la hostilidad o indiferencia de su cotidianidad frente a lo establecido y normado de una sociedad. Estos entornos los encontramos en los múltiples fenómenos generados por los medios digitales de comunicación audiovisual como se presenta en este análisis.

Esta experiencia de aprendizaje en construcción, se basó en recabar datos sobre uno de mis objetivos que busca entender las representaciones de la realidad dentro de los contextos de rodaje, escenografías y temáticas que producen los productores audiovisuales. Esta etnografía audiovisual la entiendo como un modo más de representación por diversos "factores endógenos y exógenos" de la misma disciplina (ROBLES PICÓN, 2012, p. 149). Mis descripciones, hallazgos y análisis conducen a la contextualización y visualización de imaginarios experimentados y captados por mi observación, participación e interacción con los productores informales y las personas que participan en sus producciones. Entendiendo por esto que ninguna investigación presenta una relación lineal entre lo que trata de representar el sujeto estudiado y el antropólogo. Primero por sus variadas intervenciones y negociaciones. Segundo, los sujetos disponen cómo quieren ser representados. Y tercero, estas representaciones acordadas recrean otras vías de entendimiento dentro del trabajo de campo, frente a nuestro análisis como antropólogos.

La etnografía audiovisual, en este sentido práctico, brinda la posibilidad de reformular posturas metodológicas del debate entre el peso de la palabra escrita y la imagen (GRAU REBOLLO, 2005). Más cuando estudiamos al sujeto desde la otredad y su subjetividad. Para esta investigación son claves los aportes contextuales y audiovisuales de los productores informales y múltiples personas que contribuyeron desde su hábitat y habitus durante esta etnografía. Ya que con ellos se fueron esclareciendo sus percepciones y experiencias. Los productores representan en sus películas más que hechos reales. Representan sueños, esperanzas, ideales que refuerzan la memoria de una familia, 
colectividad, sociedad, ciudad o país. Estas representaciones suponen un encuentro del entorno o contexto hostil, negado, invisible, del capital material y cultural del sujeto. Que trata de mediar y apaciguar tensiones entre el espacio de vulnerabilidad de los sujetos personificados en las películas y el otro (espectador) que señala, estigmatiza y estereotipa.

Estas representaciones audiovisuales para su universo inmediato no pueden comprenderse fuera del contexto ecológico y humano en que está inscrita, ni fuera de las temáticas sociales que brinda. Por sus escenarios naturales, sin intervención, ni modificación alguna son clave a la hora de entender y conocer la cultura material de esta sociedad, (MACDOUGALL, 1995), (CRAWFORD; POSTMA, 2006).

Así, las narrativas audiovisuales de productores informales se van posicionando en una doble relación entre simbiosis de la realidad y una posición ficcional. Sus representaciones, subjetividades, auto-representaciones y experiencias en sus producciones visibilizan una realidad ausente que para otros contextos, personas e instituciones estatales se presentan distantes. Por ello, en sus producciones es difícil separar la realidad de la ficción. Los puntos de intersección entre las representaciones de la realidad y la ficción son los que permiten abordar los contextos, la cultura material y experimental en los que se desarrollan estas narrativas.

\section{Referencias Bibliográficas}

ADESOKAN, Akin. Visiones de Lagos: urbanismo didáctico en el cine de Nollywood. Bifurcaciones Revista de Estudios Culturales Urbanos, n. 17, pp. 1-17, 2014.

ALVEAR, Miguel., \& LEÓN, Christian. Ecuador bajo tierra: videografías en circulación paralela. Quito Ecuador: Editorial Ochoymedio, 2009.

ANDERSON, Benedict. Comunidades imaginadas. Reflexion sobre el origen y la difusion del nacionalismo. México DF: Fondo de Cultura Económica, Ed. segunda. 1993.

BOUDREAULT-FOURNIER, Alexandrine., NOVAES, Sylvia; HIJIKI, Rose. S. «Fabricar

o Funk em Cidade Tiradentes, São Paulo: performance em etnoficção», CulturesKairós [En ligne], pp. 1-22, 2017.

BOURDIEU, Pierre. El sentido práctico, Madrid: Edtorial Taurus, 1991.

Espacio social y génesis de las clases en: BOURDIEU, Pierre. Sociología y cultura. México: Editorial Grijalbo 1990, p. 281-310.

La economía de los bienes simbólicos en: BOURDIEU, Pierre. Razones prácticas. Sobre la teoría de la acción. Barcelona: Editorial Anagrama, 1999, p.159-198. Espacio social y poder simbólico en: BOURDIEU, Pierre. Cosas Dichas, págs. 
127-142. Barcelona: Editorial Gedisa, 2007a.

Los tres estados del capital cultural en: BOURDIEU, Pierre. Campo del poder y reproducción social. Córdoba: Ferreyra Editor, Colección Enjeux, 2007b, p. 195-202.

Espacio social y poder simbólico en: BOURDIEU, Pierre. Cosas Dichas.

Barcelona: Editorial Gedisa, 2007, p.127-142.

BOURDIEU, Pierre; WACQUANT, Loïc. Una invitación a la sociología reflexiva, Buenos Aires: Siglo XXI, 2008.

BUSTAMANTE, Emilio; LUNA, Victoria. El cine regional en el Perú. Revista Contratexto, n. 22, pp. 89-212. 2014.

CAPDEVIELLE, Julieta. "El Concepto de Habitus: Con Bourdieu y Contra Bourdieu." Anduli: Revista Andaluza de Ciencias Sociales , n.10, 31-45, 2011.

CRAWFORD, Peter. Lan; POSTMA, Metje. Reflecting visual ethnography : using the camera in anthropological research. In: CRAWFORD, P. I; POTSMA, M. (Eds.) Hojbjerg: Routledge; Pap/DVD edition. January 1, 2006.

GRAU REBOLLO, Jorge. "Los límites de lo etnográfico son los límites de la imaginación”.

El legado fílmico de Jean Rouch. AIBR: Revista de Antropología Iberoamericana. n.41, p. 1-21. 2005.

GUARINI, Carmen; DE ANGELIS, Marina. Antropología e imagen Pensar lo visual. S. Soleil, Ed. Nanook. Ciudad Autónoma de Buenos Aires, Argentina. 2014.

GUARNÉ, Cabello. Blai. “Imagenes de la diferencia. Alteridad, discurso y representación.” In E. Ardèvol \& N. Muntañola (Eds.), Representación y cultural audivisual en la sociedad contemporanéa (UOC, pp. 47-127). Barcelona, España. 2004.

LÉVI-STRAUSS, Claude. El pensamiento salvaje. Fondo de Cultura Económica, Ed. Primera en Bogotá, Colombia. 1997.

MACDOUGALL, David. “¿De quién es la historia?” In E. Ardevol \& L. Pérez (Eds.), Imagen y cultura: perspectivas del cine etnográfico. Biblioteca, pp. 401-422. Granada, España. 1995.

MÉLICE, Anne. Un concept lévi-straussien déconstruit: le «bricolage». Les Temps Modernes, n. 656, 83-98. 2009.

OBRADORS, Matilde. Abrazar la existencia: Territorios de "realidad" y territorios de "ficción” en la creación cinematográfica. Univesidad Pompeu Fabra. Revista de Comunicació Audiovisual. n. 4, pp.1-13. 2005.

RAPOSO, Quintana. Gabriela. Narrativas de la imagen: Memoria, relato y fotografía. Revista Chilena de Antropología Visual, n. 13, pp. 79-103. 2009.

ROBLES PICÓN, Juan. Ignacio. El lugar de la Antropología Audiovisual: espacios profesionales y metodologías participativas. Íconos. Revista de Ciencias Sociales. n. 44, p.147-162. 2012. 
RODRÍGUEZ HERRERO, Virginia. Cine, sociología y antropología. La construcción social de la ficción cinematográfica. Gazeta de Antropología. n, 13 pp. 271-305. 2012.

SILVA E., Juan. Pablo. Campo de poder: los pueblos originarios en el cine de ficción y en el documental chileno. Boletín Del Museo Chileno de Arte Precolombino, V, 11 n,1.pp. 45-54. 2006

TORRES EGAS, Victor. Hugo \& TORRES LÓPEZ, Victor. Hugo. Santo Domingo: Cantón-Provincia: Ed. COBOSCREAT. Santo Domingo de los Colorados, Ecuador. 2009.

VACA, Pinto. Juan. Pablo. CHONEWOOD: Etnografía, Cine Popular y asesinato por encargo en Chone. Tesis: (Flacsoandes)- Maestría en Antropología Visual y Documental Antropologíco. FACULTAD LATINOAMERICANA DE CIENCIAS SOCIALES SEDE ECUADOR, 2015.

ZAMORANO, Claudia. El habitar y la cultura: Perspectivas teóricas y de investigación. Sociológica México, n, 83, p. 283-289. 2014.

autor Eduardo Fabio Henríquez Mendonza

É doutorando em Antropologia Social e Cultural pela Univeridade Autônima de Barcelona.

Recebido em 18/05/2017 Aceito para publicação em 12/11/2018 